doi: 10.19090/i.2019.30.256-271

UDC: $327(497.1: 450) “ 1939 / 1941$ “

ISTRAŽIVANJA

JOURNAL OF HISTORICAL RESEARCHES

30 (2019)
ORIGINAL SCIENTIFIC PAPER

Received: 18 February 2019

Accepted: 14 April 2019

BOJAN SIMIĆ

Institute for Recent History of Serbia

smcbjn@yahoo.com

\title{
ITALIAN DIPLOMACY ON MILAN STOJADINOVIĆ AFTER HIS FALL FROM POWER*
}

\begin{abstract}
Based on primary sources, memoirs, and the relevant literature, this paper examines the attitude of Italian diplomacy towards Milan Stojadinović, a former Prime Minister and Minister of Foreign Affairs of the Kingdom of Yugoslavia, after his fall from power in February 1939. The abovementioned refers primarily to the Foreign Minister, Count Galeazzo Ciano and Italian envoys in Belgrade Mario Indelli and Francesco Mamelli, but it also includes other diplomats and the Italian press.

Keywords: Italy, Yugoslavia, Milan Stojadinović, diplomacy, propaganda.
\end{abstract}

Shortly after he became Prime Minister and Minister of Foreign Affairs in June 1935, Milan Stojadinović expressed his desire to improve relations with Italy, which was, with reason, seen as the greatest threat to inter-war Yugoslavia. Such a position was regarded as a continuation of the position first taken by King Aleksandar. It was endorsed by Prince Regent Pavle and at least in its early stages it was supported by the English. The Fascist leader Benito Mussolini, who was preparing to attack Ethiopia, followed a similar line of thought. He was advised to do so by Germany, which had its own economic interests in the Balkan region. Even so, reaching an agreement was neither fast nor easy, above all because of mutual distrust, but also because of the sanctions imposed by the League of Nations condemning Italy's aggression in Africa. The actual negotiations were not conducted until late 1936 and early 1937 and they resulted in the signing of the Belgrade Pact on 25 March.

The treaty that was signed with Italy was favourable to Yugoslavia in many respects (the guarantee of territorial integrity, the issue of Ustasha emigration, the status of minorities), but its enforcement depended on the political will of Rome. ${ }^{1}$ In other words, the agreement could be blocked or broken at any time the Fascist government thought necessary.

\footnotetext{
This article has been written within the framework of the scholarly project Tradition and Transformation Historical Heritage and National Identity in Serbia in the 20th Century (№ 47019), financed by the Ministry of Education, Science and Technological Development of the Republic of Serbia.

1 On the treaty, see Avramovski 1968: 261-317; Hoptner 1972: 94-116; Krizman 1979: 65-79; Milak 1987: 132-141; Bucarelli 2006: 327-383.
} 
It was therefore essential to maintain good relations at all times. While Stojadinović was in power, the Italians adhered to the agreement to a greater or lesser degree.

In his dealings with Italy, Prime Minister Stojadinović was frequently insincere; he exaggerated, flattered, deceived... He oftentimes sought to use its rivalry with Germany within the Axis in order to accomplish his designs more easily. Across the table he found a man with a similar outlook and a similar mentality, Count Galeazzo Ciano, who had served as Foreign Minister since 1936. The two had a friendly relationship, which evolved both through direct contact and through intermediaries, primarily the diplomatic representatives of the two countries. They frequently exchanged opinions, and even documents, on topics of mutual interest, but there were also direct requests to work in accordance with Italian interests, as well as the interests of Yugoslavia. These requests were mainly related to Stojadinović's actions within the Little and Balkan Ententes on the one hand, and with Italian influence on revisionist countries on the other. The initiatives were at times successful, at other times only partly so, but there were also times when Stojadinović could not and did not want to meet the requests in question. He did not turn them down directly, of course, instead he employed all sorts of excuses.

Stojadinović's policies towards Italy also had an important domestic policy component, namely the Croatian question, i.e. the question of the Croatian people's status in Yugoslavia. The issue had burdened the country practically since its formation. In the late 1920 s, Italian diplomats took a keener interest in the issue, seeing it as a way to break up Yugoslavia. They even began collaborating with Croatian emigration, particularly with the Ustashas, who were led by Ante Pavelić. ${ }^{2}$ Stojadinović would not accept the solution proposed by the Croatian politicians in the country because it would mean, even in the bestcase scenario, the federalization of the country. He attempted to convince the leader of the Croatian Peasant Party (HSS) Vladimir Maček to accept 'a small solution', namely that a few of his party's representatives enter the government, which Maček declined. ${ }^{3}$ Since he regarded federalization as the suicide of the country, Stojadinovic tried to use his cooperation with Italy to deprive the Croats of external support and force them to accept his proposal. He achieved partial success. Official Italy did stand by him, but Maček definitively refused any kind of cooperation with him. Maček's position in the country strengthened, which became clear after the elections in December $1938 .{ }^{4}$ Prince Pavle decided to address the Croatian question, but he saw his Prime Minister at the time as an obstacle. Working with the Slovenian and Bosnian sections of the ruling party, as well as with some Serbian ministers led by Dragiša Cvetković, he took down Stojadinović's government, stating as the main reason precisely the necessity of solving the Croatian question. The resignation Stojadinović was forced to submit in early February 1939 marked his definitive departure from government, even though neither he nor his Italian friends realized it at the time.

The period between 1939 and 1941, that is, the period after the fall of Stojadinović's

Milak 1988: 92-97.

Boban 1970: 190-200; Svirčević 2013: 88-95; Bakić 2018: 212-220.

The opposition bloc led by Maček, which also included representatives of the Serbian United Opposition, won $45 \%$ of the vote in the election. 
government, represents a special time in Italo-Yugoslav relations. Once again there followed a period of distrust, support for Croatian separatism, and work towards breaking up the Yugoslav state, which culminated in naked aggression in spring $1941 .{ }^{5}$ We shall try to determine why this was so and whether Stojadinović was, as the historian Luciano Monzali put it, "the man on whom all hopes were placed", 6 by analyzing Italian diplomatic and other sources in the period between Stojadinović's fall and the April War.

The Italian diplomatic service was well informed about the developments in Yugoslavia and the actions of the Prime Minister, even when the official published information differed from reality quite substantially. An example of one such case was the visit of the Polish Foreign Minister Colonel Jozef Beck to Yugoslavia in May 1936. The Italians observed the visit with special interest and had much more precise information about it than, for example, the British Legation in Belgrade. ${ }^{7}$ As we shall see, this depended on who provided the information in question, Stojadinović or Prince Pavle. One was known as a man close to the Italians and the other one to the English.

During a visit to Belgrade in January 1939, Ciano had an important meeting with the Italian envoy Indelli (stationed in Belgrade from 1936 until 1940) and with the Italian press. Indelli warned his boss that Stojadinović's position did not seem safe. He pointed to the fact that Prince Paul wanted to come to an agreement with the Croats and that Maček refused to cooperate in any way with the then Yugoslav Prime Minister, who wanted an authoritarian regime. To all that, Indelli added the democratic tradition of most parties, as well as the election results which gave Stojadinović only a slight advantage over the opposition. Ciano replied that he would go back to supporting Croatian separatism in the case of Stojadinović's fall. In the end he concluded: "I implement policies with Stojadinović, I do not intend to pursue them with others". 8

Stojadinović's fall from power did not make the leading people of the Fascist regime lose interest in him. The desire that he return to power was openly expressed from time to time. The situation with the German diplomats was similar. According to Vladislav Stakić, the Prince's emissary for conversations with Mussolini and Ciano: "concerning Stojadinović, the Germans and the Italians would not leave us alone. They periodically brought that issue back to the table". ${ }^{9}$ The sources we shall mention go in favour of this view.

For Mussolini and Ciano, Stojadinović's departure from the government came as an unpleasant surprise. In his diary entry for the day when he received the news from Belgrade, Ciano wrote that Stojadinović's position had seemed safe and that he himself had only fourteen days before he was assured by Stojadinović that nothing and no one could push him out of power. ${ }^{10}$ Miloš Crnjanski, who was at the time Press Attaché at the Legation in Rome, later wrote that "Ciano was so surprised by Stojadinović's fall that he asked everyone everywhere about it. He asked not only Hristić, our envoy in Rome, after his return from

\footnotetext{
5 On Yugoslav-Italian relations 1939-1941, see Vinaver 1966: 73-94; Vinaver 1968: 67-112; Krizman 1979: 79-93; Monzali 2010: 76-100.

Monzali 2010: 74.

Simić 2017: 129-142.

Russo 1944: 76-77.

Stakić 1967: 75.

Ciano 2010: 248.
} 
Belgrade, but also Stojadinović himself, through the journalist Gayda. He even asked two young musicians whose performance in Belgrade he had enjoyed so much that he invited them to Rome as guests". ${ }^{11}$ Mussolini was furious. He concluded that Stojadinović's fall constituted evidence that the Germans were the only ones with whom one could not make reliable deals. All of that had to do with the talks about the partition of Albania which were held with Stojadinović during Ciano's visit to Belgrade that January. ${ }^{12}$ After receiving the unfavourable news, the Duce concluded: "If we come to an agreement with Stojadinović, the division of Albania [will be] between us and Yugoslavia; without Stojadinović, the occupation of Albania [will happen] without Yugoslavia, if need be against it". ${ }^{13}$ On the following day, 6 February, Mussolini told Ciano that the elimination of Stojadinović was a true coup carried out by the Prince Regent who wanted to prevent the "stabilization of a fascist dictatorship in Yugoslavia". ${ }^{14}$

On 7 February Mussolini and Ciano already had a clearer picture of the situation. Based on the information they had received from Indelli, they could conclude that Pavle really was at the heart of the conspiracy against Stojadinović. Although Ciano had believed that Stojadinović's position was getting stronger, he realized that it was not solid enough to confront the coalition that had been created against him with the help of the Prince. The decision was to speed up the operations in Albania, which would take place as early as the beginning of April. In terms of the "Yugoslav card", it was concluded that it had lost $90 \%$ of its value with the departure of Stojadinović. ${ }^{15}$ The reports of the Ambassador in Berlin Bernardo Attolico also suggested that Stojadinović's removal was directed against the Axis powers. In fact, he claimed that Stojadinović's fall had been provoked by large Western democracies and that they had even used financial resources for the purpose. This came from a conversation that Attolico had with the general Efisio Marras, Military Attaché in Berlin. He later conveyed the information that Marras had obtained. ${ }^{16}$

Indelli was very active when it came to finding the cause and the background of the action against Stojadinović. On the day of the Prime Minister's resignation, he called his assistant Ivo Andrić and inquired about it and about whether Stojadinović would at least remain as Minister of Foreign Affairs. When he was not given any kind of definitive answer, he said: "That is a very serious matter. We are in this with Mr. Stojadinović". ${ }^{17}$ In the days that followed, Indelli continued to examine the situation. The information from 7 February, which Indelli reported to Rome, namely that Prince Pavle was at the heart of the conspiracy to overthrow Stojadinović, had come directly from the former Prime Minister. In a long conversation they had that day Stojadinović expressed his thoughts on the ongoing situation

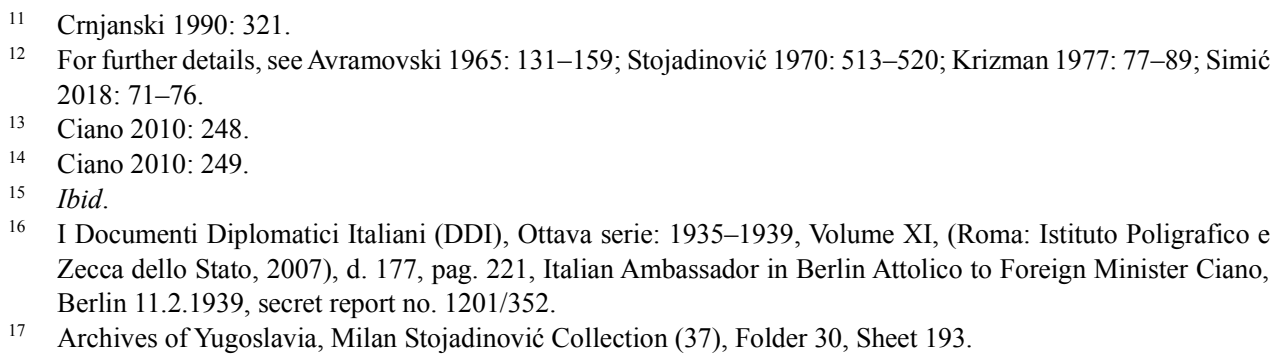
Zecca dello Stato, 2007), d. 177, pag. 221, Italian Ambassador in Berlin Attolico to Foreign Minister Ciano, Berlin 11.2.1939, secret report no. 1201/352.

17 Archives of Yugoslavia, Milan Stojadinović Collection (37), Folder 30, Sheet 193. 
and his dilemmas on how to proceed. As the cause of the fall, he mentioned the Prince's fear of his growing central position in the political life of the country. As for his future plans, Stojadinović said that some of his party comrades advised him to temporarily withdraw from politics, whilst others encouraged him to fight against the new government, which would effectively be a fight against the Regent. The conclusion was that the future was uncertain and that the new government was being run by people with little experience and few followers. In the end, Stojadinović thanked Indelli for the support he was receiving from the Italians at the time. ${ }^{18}$

Prince Pavle took the initiative and summoned Indelli to explain the reasons for the change in government. It seems that the meeting took place on 16 February. There are two documents about it; the shorter one was sent to Ciano on the same day and the longer one two days after that. During the course of the cordial and amicable conversation, which was prompted by advice of the new Minister of Foreign Affairs Aleksandar Cincar-Marković, the Prince provided ample justification for Stojadinović's removal from power. Of course, he only mentioned those reasons which had to do with internal affairs. He began with the Concordat crisis of 1937 which had put the country in danger and after which Stojadinović became "the least popular man in the country". The situation stabilized with Pavle's intervention, but Stojadinović continued to use his method: "promise everything to everyone, then count on your lucky star to weasel your way out of an unpleasant situation". ${ }^{19}$ It was allegedly only the election campaign of 1938 that opened the Prince's eyes to the united opposition comprised of all peoples against Stojadinović, poor election results... The situation worsened when Anton Korošec was removed from the government and when, according to the Prince, there were also plans to remove the other pillar of the party, Mehmed Spaho, the representative of Bosnian Muslims. Pavle stated that the party members from the interior of Serbia had started to gather around Cvetković and that the overthrow of Stojadinović by all these united opponents was supposed to happen back in January, but that it was postponed precisely because of Ciano's visit. It was, the Prince related, impossible "not to accept Stojadinović's resignation and remain alone by his side, with few people who had no support or considerable standing, and take a stance against the entire country, with the danger that Korošec would also take the side of Zagreb". ${ }^{20}$ It is clear that the Prince was trying to conceal his role in the whole affair, portraying himself as someone who had been presented with a done deal.

Later on in the conversation, the Prince praised Stojadinović's work, especially in terms of foreign policy, and highlighted his loyalty and capability. His words were such that Indelli concluded and wrote the following: "I believe, therefore, that nothing will prevent this collaboration from continuing after a while, when his domestic policy errors are forgotten". ${ }^{21}$ Of course, the Prince emphasized that the policy towards Italy would not change and that he would personally confirm this during his next visit. Indelli concluded

18 DDI, Ottava serie, Volume XI, d. 162, pag. 205, Italian envoy in Belgrade Indelli to Foreign Minister Ciano, Belgrade, 7.2.1939, confidential report no. 491/24 R.

19 DDI, Ottava serie, Volume XI, d. 198, pag. 244-245, Italian envoy in Belgrade Indelli to Foreign Minister Ciano, Belgrade, 18.2.1939, confidential report no. 842/257.

Ibid. 245-246.

21 Ibid. 246. 
his report by plainly observing that Pavle had the intention, like King Aleksandar, to take all key matters into his own hands. The ensuing developments in Yugoslavia would go to show that this remark was correct. Incidentally, both Pavle and some time later Indelli spoke about how Yugoslav policies towards Italy at the time were rooted in the people and how they transcended any individual. ${ }^{22}$

After returning from Belgrade in the second half of February, the envoy Boško Hristić seemingly spoke to Ciano on several occasions. First, he confirmed that Yugoslavia's foreign policy would not undergo any changes. Later, Ciano writes, he "poured his heart out" and spoke in Stojadinović's favour. He said that the Prince's jealousy had played a significant role in Stojadinović's fall and that he hoped Stojadinović would regain power in the subsequent few months. ${ }^{23}$ It is not clear enough whether Hristić was being completely honest or if his statement was just a political maneuver, but the fact that he had more respect for Stojadinović than he did for his successor to the post of Minister of Foreign Affairs was later noted by Crnjanski as well. ${ }^{24}$ Ciano also believed that Hristić was fond of Stojadinović and he put it in writing after a conversation they had in February $1938 .{ }^{25}$ Even in March 1939, during the preparations for the two-year anniversary of the Pact, Hristic still expressed his faith that Stojadinović would return when "the current government fails in its negotiations with Maček". ${ }^{26}$

The fall of Stojadinović and the ongoing situation in Yugoslavia were among the topics discussed by Mussolini and Goering in April 1939 in Ciano's presence. Goering, who was seen as an expert on Yugoslavia, was running the show. As for the reasons for the fall, he mentioned the will of the British and the fact that Stojadinovic had become too powerful. He detailed what the ministerial crisis looked like and stated that it had come as a complete surprise to Germany. It was also mentioned that the Yugoslav side had tried to discredit Stojadinović in the eyes of the Axis powers and to blame him for different things, but that these accusations were, "in all likelihood, false". The leading members of the Axis concluded that Stojadinović was, "at any rate, a sensible man and a better partner for Italy and Germany than his worthless successor". ${ }^{27}$

Prince Pavle used his stay in Italy in May 1939 as an opportunity to personally give explanations regarding Stojadinović's fall. This time, he remarked that the main reason for the fall had been the great wealth that Stojadinović and his associates had amassed through "suspicious business activities", especially abroad. Pavle even hinted at the possibility of legal action on that matter. Ciano advised him against the idea, but he was not certain that his words were taken into consideration. The Prince Regent had stated the same reasons in an earlier conversation with Mussolini. ${ }^{28}$ Interestingly, Stojadinović only found out about the Prince's statement from a letter he received on Mauritius in early 1947. He then noted that he was left

Ibid. 248.

Ciano 2010: 254, 256.

Crnjanski 1990: 328.

Ciano 2010: 96.

Ciano 2010: 263.

"An excerpt from the minutes of a meeting between Goering and Mussolini, in the presence of Count Ciano, about the Axis powers' policies towards Yugoslavia, on 15 April 1939", Aprilski rat 1941: 178.

28 Ciano 2010: 296. 
with only 50 pounds sterling in a bank in London and another 2000 francs in Paris. "All that would not even suffice for one month's living expenses", he concluded at the time. ${ }^{29}$

During the month of June, after the occupation of Albania, the Italian envoy in Budapest Luigi Vinci reported the news he had received from Yugoslav diplomatic sources back to headquarters. He claimed that the Yugoslav public had received Italian action with a degree of ill will, while Stojadinović criticized the then government for not requesting certain territories as compensation, above all Shkodra and Mount Tarabosh. ${ }^{30}$ This reaction is not surprising since there is no doubt Stojadinović had precisely Shkodra in mind during his negotiations with Ciano in January 1939.

Also in June, Indelli wrote how it seemed that the process of solving the Croatian question was entering its final phase. He had received this information from Prime Minister Cvetković himself. At the time, Indelli was not familiar with the details of the agreement, but he assumed that Maček had given up on some of his initial demands. Once again, Indelli did not miss the opportunity to draw attention to Stojadinović's position if they actually managed to come to an agreement. Not at all optimistically, but completely accurately, he concluded that it would "equal if not the end, then at least the long dusk of his political life". ${ }^{31}$ The German emissary to Yugoslavia Johannsen also saw Cvetković's failure to come to an agreement with the Croats as the only way to reinstate Stojadinović. However, he underlined that the reinstatement was tied to the personality of Prince Pavle, who had an unfavourable attitude towards him, and that it was unlikely he would in any way, shape or form appeal to Stojadinović anytime soon. ${ }^{32}$

Stojadinović's old friend from Bulgaria, Prime Minister Georgi Kyoseivanov, did not forget about him either. In a conversation with Talamo, the Italian envoy in Sofia, regarding the ongoing situation during the summer of 1939, Kyoseivanov highlighted that, unlike Stojadinović, the then Yugoslav government would not even guarantee him neutrality in case the provisions of the Balkan Pact were enforced. He judged the situation in Yugoslavia as "murky" and "unfavourable for the Axis powers", so he hoped that Stojadinović, who was actively working on it, would return. ${ }^{33}$ The Bulgarians' grief for Stojadinović is not surprising either, especially if we have in mind the meeting in Niška Banja in late 1938 and the discussions that took place then, with Kyoseivanov proposing a joint Bulgarian-Yugoslav action against Greece. ${ }^{34}$

Indelli's report from 18 November 1939 is wholly concerned with Stojadinović's activities in the opposition in Yugoslavia after the Cvetković-Maček Agreement. He described the content of a leaflet which was circulating in Belgrade at the time. The leaflet suggested that the Agreement was not a Serbo-Croatian one because Cvetković represented

29 Stojadinović 1976: 165.

30 DDI, Ottava serie, Volume XII, d. 93, pag. 73, Italian envoy in Budapest Vinci to Foreign Minister Ciano, Budapest, 2.6. 1939, courier dispatch no. 156.

31 DDI, Ottava serie, Volume XII, d. 313, pag. 255, Italian envoy in Belgrade Indelli to Foreign Minister Ciano, Belgrade, 22.6.1939, courier dispatch no. 29.

32 Aprilski rat 1941.: 289

33 DDI, Ottava serie, Volume XII, d. 559, pag. 421-422, Italian envoy in Sofia Talamo to Foreign Minister Ciano, Sofia, 13.7. 1939, courier dispatch no. 110.

34 Avramovski 1986: 284. 
neither his party nor the Serbian people, that it was breaking up the country, and it called on all Serbian people to fight for the country's unity. Indelli, however, got the impression that Stojadinović himself was an even greater pessimist than could be concluded from the leaflet's content. He related the details of a conversation between Stojadinović and a correspondent for the Stefani agency, most likely Corrado Sofia. According to him, the former Prime Minister of Yugoslavia considered "the eventual separation of Croatia from the rest of Yugoslavia as inevitable". During that conversation, Stojadinović allegedly stated that the Serbian people should form as close as possible a union with Bulgaria, whose people were closer to them "in both blood and mentality than the Croats", though he admitted that the idea still was far from being realized. ${ }^{35}$ The Italians' impression was that Stojadinovic blamed Prince Pavle for his fall and that he had been sacrificed because of the Croats and because of Maček's animosity towards him. The conclusion was that he wanted to use the widespread public discontent after the Agreement and turn it to his own advantage. Indelli also confirmed that Stojadinović maintained very close relationships with the Germans. ${ }^{36}$ This referred primarily to the German envoy von Heeren. Stakić mentioned some "Gestapo agents" as well, but he did not provide their names or any other, more precise details about those meetings. ${ }^{37}$

Ante Pavelić, the leader of the Ustasha organization, was also well-aware of Stojadinović's high standing among the top figures of the Fascist regime. During a meeting with Ciano in January 1940, when he was presenting his plans to mount an uprising in Croatia and break up Yugoslavia with the help of 30,000 Italian soldiers, Pavelić left open the possibility of forming a Serbian state "in the territories of the old Serbian Kingdom". At this point he also mentioned Stojadinović, ${ }^{38}$ whom he assumed the Italians would want as its leader. ${ }^{39}$ In the minutes of the meeting, which were edited by Ciano's secretary Filippo Anfuso, the part which talks about the potential new government in Belgrade says: "possibilmente quello di Stojadinović" (possibly that of Stojadinović). Stojadinović is not mentioned again in the remainder of the document or in the appendix, so it cannot be claimed that any kind of agreement was reached on that issue. Vladeta Milićević, the delegate of the Yugoslav Ministry of Interior to Rome responsible for the Ustasha organization, argued in his report from July 1941 that precisely this meeting played a key role in the Italian decision to pursue the breakup of Yugoslavia with the assistance of Pavelić. According to him, everything that came later was "strategizing and maneuvering in accordance with the political winds". ${ }^{40}$ Many years later, after the Second World War in faraway Argentina, Pavelić would happen to discuss the demarcation of the border between the Serbs and the Croats after the overthrow of Tito's regime precisely with Stojadinović. ${ }^{41}$

35 DDI, Nona serie, Volume II, d. 261, pag. 221-222, Italian envoy in Belgrade Indelli to Foreign Minister Ciano, Belgrade, 18.11.1939, dispatch no. 5306/1453; Aprilski rat 1941.; 288-289, fn. 2.

36 Ibid. 222

37 Stakić 1967: 74.

38 DDI, Nona serie, Volume III, d. 194, pag. 163, Meetings between Foreign Minister Ciano and Pavelić, Rome, 23.1.1940, a note from the meeting.

39 Breccia 1978: 241; Krizman 1978: 324-333.

$40 \quad$ Milićević 2018: 117.

41 Đurković 2013: 24-26. 
The reaction of the Axis powers after Stojadinovićs arrest in 1940 also speaks to the fact that they did not want to give up on him completely. Ciano asked the new Italian envoy in Belgrade, the experienced diplomat Mameli, to reach out to the Yugoslav government and inquire about the reasons for Stojadinović's arrest. Mameli was given the explanation that the arrest had happened for purely internal reasons. He nevertheless remained unconvinced, stating that the arrest had been interpreted as an "anti-German and, to a somewhat lesser degree, anti-Italian act", for which it was sufficient to open any "French or English newspaper". ${ }^{42}$ The government tried to confute the reports of the foreign press by vehemently denying them through the semi-official Avala agency, where they emphasized that foreign policy reasons were not behind the measures that had been taken. The press release further stated that Stojadinović had been detained pursuant to Article 12 (a) of the Protection of Public Security and Order Act, "so as to prevent him from taking any further action against the domestic policies of the Royal Government". ${ }^{43}$

Some ten days after that, Prime Minister Cvetković took advantage of a reception at the Hungarian Legation to take the initiative and personally explain the situation concerning Stojadinović to Mameli. In the introduction, he told him that he was aware of the cordiality and great friendship that existed between Ciano and Stojadinović. Still, he insisted that the imprisonment was a purely internal affair and that Yugoslav foreign policy had not changed. Instead, he claimed, it had been strengthened, particularly in the case of Italy, for which he had personally advocated. ${ }^{44}$ During the conversation, Mameli noticed that Cvetković had a certain kind of aversion towards his predecessor, so he emphasized this in his report. All subsequent events showed that his remarks were entirely appropriate.

During Stojadinović's internment, the reactions of the Axis representatives were even fiercer. On 25 June, after receiving from his representatives the news that his friend's life was in grave danger, Ciano reacted by immediately contacting German representatives. They acted promptly with the aim to "save Stojadinović's life". ${ }^{45}$ Alfio Russo wrote that Italy was prepared to sever diplomatic ties when the news appeared and that, for them, Stojadinović's murder would be a casus belli! ${ }^{46}$ Both Axis envoys in Belgrade reacted to the rumours about the possible murder of Stojadinović. The reaction of the German representative Viktor von Heeren was particularly harsh. Prince Pavle allegedly responded that he was not a murderer and that not a single hair would go missing from Stojadinović's head. He went a step further, assuring the German envoy that it was he who instigated the friendly policies towards the Axis and that, in doing so, he had to overcome a certain kind of resistance from Stojadinović. In his report, Heeren concluded that the Prince would do whatever it took to keep the former Prime Minister safe, but that he would keep refusing to collaborate with him in the future. ${ }^{47}$ In Rome, Crnjanski also heard the rumours that

42 DDI, Nona serie, Volume IV, d. 343, pag. 273, Italian envoy in Belgrade Mameli to Foreign Minister Ciano, Belgrade, 9.5.1940, courier dispatch.

43 Vreme, 24 April 1940, 6.

44 DDI, Nona serie, Volume IV, d. 531, pag. 417, Italian envoy in Belgrade Mameli to the Foreign Minister's Head of Staff Anfuso, Belgrade, 21.5.1940, private confidential note no. 2033.

45 Ciano 2010: 446.

46 Russo 1944: 77.

47 Biber 1966: 56, fus. 190. 
Stojadinović had been executed, at which point he intervened both with the Italian press and with foreign correspondents and denied the rumour. ${ }^{48}$ Stojadinović would later claim that it was precisely the protest of Italian and German diplomats that saved his life at that time. ${ }^{49}$

In June 1940, there were rumours about Stojadinović's return to the post of Minister of Foreign Affairs after the reconstruction of the Cvetković government. Mameli claimed that he received that information directly from the German envoy von Heeren. In such an event, Cincar-Marković would return to Berlin and Ivo Andrić would resume his old post next to Stojadinović. Mameli wondered whether these were predictions or desires. ${ }^{50}$ Given that there are no affirmations about such a combination from the Yugoslav side, it is clear that these were only the desires of the German representative in Belgrade. It seems that the Italians reached out to Prince Pavle to ask about the possibility of Stojadinović's return through other sources as well. In August, they received a response "from a notable source", saying that the Prince thought Stojadinović's return, which the Axis wanted, would lead to open conflict with the Croats. ${ }^{51}$

Among those from the Yugoslav side who admitted that Stojadinović's removal from government had been a mistake was Miloš Crnjanski. During a conversation with one of the leading journalists of Mussolini's regime Virginio Gayda in June 1940 in Rome, he said that Stojadinović's removal and policies which were less favourable to Italy were the result of Maček's actions. It seems that Crnjanski had initiated the whole conversation, because he spoke openly about Prince Pavle's favourable attitude towards England and said that he was maneuvering "between political realism and his deep-rooted sympathies". ${ }^{2}$ Even so, his statements, like Hristić's earlier ones, indubitably gave Italian power holders the hope that Stojadinović's return was nevertheless possible.

Incidentally, the aforementioned Gayda had his own interpretation of the causes for Stojadinović's removal. In an article after the fall, he claimed that it was an internal matter, ${ }^{53}$ only to change his mind in the second edition of his book aimed against Yugoslavia, titled Yugoslavia against Italy: Documents and Revelations. In it he said that it was a conspiracy within Serbian military circles in agreement with the French and British ones. ${ }^{54}$ It is clear that the second interpretation served to justify the 1941 spring aggression.

During the summer of 1940, the British also wrote about Italy's desire that Stojadinović return to power. After a conversation with Prince Pavle, the British envoy Ronald Campbell reported to London that he had learnt the Italians were putting more pressure on the issue than the Germans. In an exchange of opinions between Campbell and the Prince, it was concluded that Stojadinović's return to power would mean giving up

\footnotetext{
“Godišnji izveštaj za 1940. godinu”, Crnjanski 1991: 178.

Stojadinović 1970: 638 .

50 DDI, Nona serie, Volume IV, d. 785, pag. 589-590, Italian envoy in Belgrade Mameli to Foreign Minister Ciano, Belgrade, 6.6.1940, confidential courier dispatch no. 100.

51 DDI, Nona serie, Volume V, d. 398, pag. 382, Italian envoy in Belgrade Mameli to Foreign Minister Ciano, Belgrade, 12.8.1940, courier dispatch no. 169.

52 DDI, Nona serie, Volume VI, d. 71, pag. 55-56, Editor of Il Giornale d'Italia Gayda to Minister of Popular Culture Pavolini, Rome, 20.6.1940, personal letter.

53 Biber 1966: 27, fn. 68.

54 Gayda 1941: 8.
} 
Croatia to the Italians with whom he was connected, because he was "one of those who thought only about Serbia and the role they could play in its expansion. That is why Ciano wanted precisely him". ${ }^{55}$ In his report from October 1940, Campbell also mentioned that Rome was advocating for Stojadinović's return. ${ }^{56}$ Later on, in October 1941, Foreign Secretary Anthony Eden also confirmed that the Germans, and even more so the Italians, were "strongly urging the Yugoslav government to reinstate him". It is particularly important to mention that, in that letter, Eden confirmed there was "no evidence that Stojadinović was really scheming with the Axis in order to return to power, or that he had the intention of becoming a quisling". ${ }^{57}$

In late 1940 and early 1941, Prince Pavle sent the lawyer Vladislav Stakić to Italy as his emissary on various occasions. He spoke with Ciano several times and with Mussolini twice a while later. These conversations revealed the attitudes of the leading Fascist figures towards the former Prime Minister of Yugoslavia. On 11 November 1940, during his first meeting with Stakić in the Chigi Palace, Ciano could not but touch upon Stojadinović. His exposition on the topic illustrates his position clearly and completely frankly, which is why we quote it in full:

\begin{abstract}
As for your domestic policies, Italy does not want to interfere in your domestic issues. The main concern for Italy is the kind of policy that will be pursued and not who will pursue it, although I can tell you right now that I was unpleasantly surprised by the fall of Milan Stojadinović. Especially when he was deposed shortly after our meeting at Belje. It is true that Mr. Hristic stated immediately after Stojadinović's fall that the policies which were pursued by Mr. Stojadinović were not his personal policies, but that these policies would be continued. I want to take that and believe in it, but my personal friendship with Mr. Stojadinović is great. Mr. Stojadinović enjoys endless friendship and trust, both from me and from the top figures of the Reich, because he was one of the first friends of the Axis in a time when the Axis star did not shine so brightly on the European sky as it does today. But friendship is one thing and politics is another. We are not hanging on to Mr. Stojadinović and we care about resolving all potential disagreements between Yugoslavia and Italy, and about establishing trust between you and us in that respect. ${ }^{58}$
\end{abstract}

It is important to mention that Stakić had been given explicit instructions, both by the Prince and by the Minister of the Royal Household Antić, to show that Stojadinović's return was impossible due to internal political reasons because the leader of the Croats Maček would not collaborate with him and the collaboration with Maček constituted the basis of the Prince's domestic policies. ${ }^{59}$ That friendship was one thing and politics another, as Ciano had said, was not at issue, but these policies were now nonetheless implemented differently. Whilst, as Crnjanski wrote, in Venice, Ciano conversed with Stojadinović "behind closed doors during a bath", with his successor Cincar-Marković he spoke "formally, in a drawing room on the first floor, where no one was allowed to pass, but the

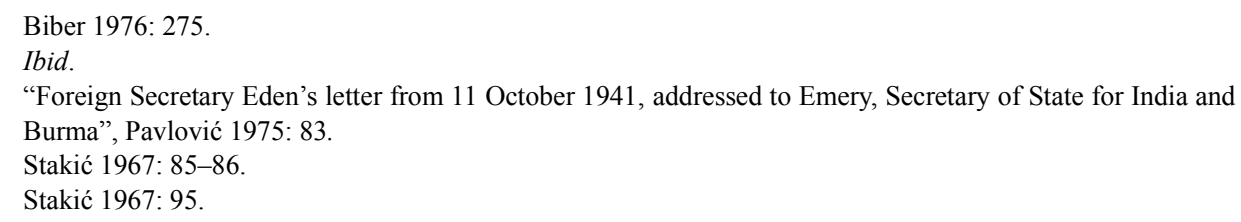


stairway was besieged by journalists all day". ${ }^{60}$

A while later, on 24 February 1941, Mussolini also mentioned Stojadinović during a conversation with Stakić at Palazzo Venezia. He particularly stressed the concession regarding the Ustashas. The Duce then said that there was a delegate of the Yugoslav Ministry of Interior in Rome whom he had personally approved and who had the right to control the actions of Croatian émigrés at any time he saw fit. Mussolini emphasized that this was a rare privilege that he had granted to "Yugoslavia because of Stojadinović's solidary attitude towards Italy". ${ }^{61}$

It is significant that, later on in the conversation, Mussolini made it very clear to Stakic that the situation with the Ustashas in the future depended on the position of Yugoslavia. In other words, if Yugoslavia was not friendly towards Italy, the Croatian factor would once again play an important role in his policies in the Balkans. ${ }^{62}$ That warning would become real some month and a half after their meeting.

Ciano subsequently changed his mind about the reasons for Stojadinović's removal from power several times. In his book, the American historian Jacob Hoptner mentions that Ciano believed the Germans had been involved in Stojadinović's fall and that it had been a maneuver against Italy with the aim of reducing Italian influence among the Croats. ${ }^{63}$ This version is based on a German document about a conversation between the Italian general Alberto Pariani and Wilhelm Keitel. Nevertheless, Ciano's own notes do not mention the suspicion that the Germans could be behind Stojadinović's fall. ${ }^{64}$ In January 1941, pressed by difficulties in the war with Greece, Ciano claimed that Stojadinovic had not fallen because of foreign policy reasons, but because the Prince wanted an agreement with the Croats. Even so, he still claimed that Italy had lost a true friend. ${ }^{65}$

On the eve of the attack on Yugoslavia in February 1941, Milan Jovanović Stoimirović brought a record of a conversation between him and Corrado Sofia, a correspondent for the Stefani agency. When Stoimirović asked whether Italy insisted on Stojadinović's return, Sofia's response was negative. At the time, his attitude was that Stojadinović was "unintelligent, although I cannot say he was without intelligence. He was lacking in something. I told Ciano that there was a flaw in his intelligence". ${ }^{66}$

The putsch of 27 May could not pass without the mention of Stojadinovic either. This time it was a letter Benito Mussolini addressed to Reich leader Adolf Hitler. In it, the Duce misinterprets the situation by claiming that Prince Pavle was familiar with and had an agreement with the putschists, but he also observes, quite logically, that Stojadinovic was handed over to the English "right before the signing in Vienna". ${ }^{67}$ Mussolini therefore asked himself what kind of a country would, a few days before signing a pact with the Axis, deliver a well-known friend of that same Axis into the hands of its enemies with whom they were at

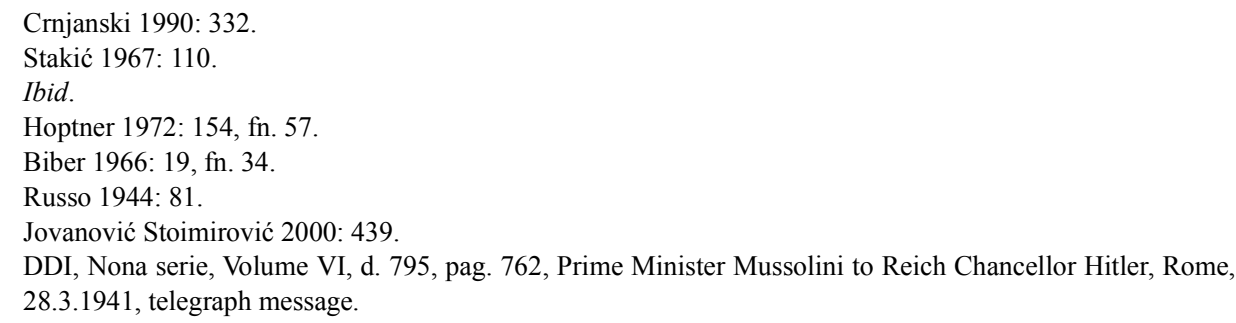


war?! Hoptner was at least partially right in claiming that Cvetković "probably exiled him because he was afraid the Germans could force the Regency to reinstate Stojadinović, a man they trusted". ${ }^{68}$ What Hoptner did not know, or did not want to mention, is the fact that it was precisely Prince Pavle who had asked the English to take Stojadinović and arranged the whole thing with Foreign Secretary Eden. ${ }^{69}$ Of course, it is not at all disputable that Cvetkovic had agreed to this and been a part of it, although he would claim otherwise after the war. ${ }^{70}$

Incidentally, it is interesting that general Dušan Simović also remembered Stojadinović after the putsch, hoping that he would be able to stop or at least postpone the German attack on Yugoslavia. Namely, he appealed to the English via their envoy Campbell and asked that the British authorities return Stojadinović at least to Athens, if not to Belgrade. Simović offered to vouch for Stojadinović, claiming that he had only been enforcing the policies of Prince Pavle. He further stated that Stojadinović was "not a dangerous man at all", that he was "unpopular and had no followers or influence", and that "the people completely rejected the policies he had implemented". ${ }^{71}$ Following explicit instructions from Churchill and Foreign Secretary Eden, Simović was given the explanation that Stojadinović was already on his way to Mauritius and that it would not be easy to organize transport for his return. In essence, the English had already announced on 21 and 22 March, first in the American press, that the Yugoslav government had extradited, as they put it, a prominent supporter of pro-Axis policies. ${ }^{72}$ All of this was a way of pressuring the Prince and the government, because they were known to be negotiating the signing of the Tripartite Pact.

As for the reason behind the attack on Yugoslavia in April 1941, Hitler said that the country "had only one strong man, Stojadinović, whom the Prince Regent had overthrown to his own disadvantage". ${ }^{73}$ In addition to the Germans, Stojadinović is mentioned in an official document by Count Ciano. In an attempt to justify the aggression, he claimed that Italy had remained loyal to the 1937 agreement, even after Stojadinović's removal from power, and "despite the tendencies for the reappearance of hostile policies towards the government in Rome". In other words, he blamed Yugoslavia for the war. ${ }^{74}$ Of course, it is clear in this case that the statement of the Italian Foreign Minister did not conform to the truth. The only thing that can be considered true is the repeatedly expressed grief over Stojadinović's fall.

From all of the above, we can positively conclude that Italian diplomacy in the period from February 1939 until the April War in 1941 grieved over the departure of Stojadinović. This applies particularly to Foreign Minister Count Ciano, with whom he had established an intimate friendship. There are two main reasons for this. They saw in Stojadinović a man with whom they could realize their plans in South-Eastern Europe most efficiently, but they also highly regarded and respected him as a person. With that in mind, they constantly put a certain amount of pressure on Prince Pavle and the members of the Cvetković government, and were even prepared to take direct action when it seemed that Stojadinović's life was in danger.

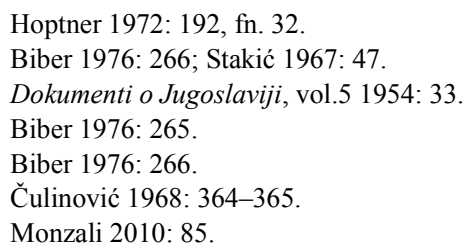




\section{REFERENCES:}

Archive sources:

Archive of Yugoslavia, Milan Stojadinović's Collection

Published sources:

Aprilski rat 1941., I, Beograd: Vojnoistorijski institut, 1969.

Crnjanski, M. Nova Evropa, Beograd: Književne novine, 1991.

Čulinović, F. Dokumenti o Jugoslaviji, Zagreb: Školska knjiga, 1968.

I Documenti Diplomatici Italiani. Nona serie: 1939-1943, Volumi I-VI, Roma: Istituto Poligrafico dello Stato, 1954-1986.

I Documenti Diplomatici Italiani. Ottava serie: 1935-1939, Volumi I-XI, Roma: Istituto Poligrafico e Zecca dello Stato, 1991-2007.

Milićević, V. Ustaša. Hrvatska revolucionarna organizacija, Beograd: Muzej žrtava genocida, 2018. (Serbian Cyrillic)

Memoirs:

Ciano, G. Diario 1937-1943, Milano: BUR Rizzoli, 2010.

Crnjanski, M. Politički portreti, Beograd: Beletra, 1990.

Dokumenti o Jugoslaviji, sv.5, Namesništvo. Unutrašnja i spoljna politika Jugoslavije, Paris: Les Presses Rapides, 1954.

Jovanović Stoimirović, M. Dnevnik 1936-1941, Novi Sad: Matica srpska, 2000. (Serbian Cyrillic)

Russo, A. Rivoluzione in Jugoslavia, Roma: Donatello de Luigi, 1944.

Stakić, V. Moji razgovori sa Musolinijem, Minhen: Iskra, 1967.

Stojadinović, M. Ni rat ni pakt, Rijeka: Otokar Keršovani, 1970.

Stojadinović, M. Zatočenik njegovog kraljevskog veličanstva, Melburn: Srpska misao, 1976. (Serbian Cyrillic)

Periodicals:

Vreme, Belgrade, 1940.

References:

Avramovski, Ž. 'O padu Stojadinovićeve vlade'. Istorija XX veka, VIII, 1966, 5-67.

Avramovski, Ž. 'Pitanje podele Albanije u razgovorima Stojadinović-Ćano januara 1939. i stav nekih diplomatskih i vojnih ličnosti’, Godišnjak Pokrajinskog državnog arhiva, Priština, 1965, 131159.

Avramovski, Ž. Balkanska antanta (1934-1940), Beograd: Institut za savremenu istoriju, 1986.

Avramovski, Ž. Balkanske zemlje i velike sile 1935-1937. Beograd: Prosveta, 1968.

Bakić, D. 'Milan Stojadinović, the Croat Question and the International Position of Yugoslavia, 1935 - 1939'. Acta Histriae 26. 1/2018, 207-224.

Biber, D. 'Britanske ocjene Stojadinovića i njegove politike'. Fašizam i neofašizam: zbornik izlaganja na Međunarodnom znanstvenom simpoziju, Zagreb, 13-15. studenoga 1975, 1976, 265-277.

Boban, Lj. 'Sastanak V. Mačeka s knezom Pavlom (u studenom 1936) i M. Stojadinovićem (u siječnju 1937)', Časopis za suvremenu povijest god. 2, br. 2 (1970), 181-211.

Breccia, A. Jugoslavia 1939-1941: diplomazia della neutralitá, Milano: Giuffré editore, 1978.

Bucarelli, M. Mussolini e la Jugoslavia 1922-1939. Bari: Edizioni B.A. Graphis, 2006.

Đurković, M. 'Uvod: Enigma Milan Stojadinović'. u Milan Stojadinović: Politika u vreme globalnih lomova, Zbornik radova, ur. Miša Đurković 7-26, Beograd: Zavod za udžbenike/Centar za 
konzervativne studije, 2013. (Serbian Cyrillic)

Gayda, V. La Jugoslavia contro L'Italia (Documenti e rivelazioni), Roma: Il Giornale d'Italia, 1941.

Hoptner, J. Jugoslavija u krizi 1934-1941, Rijeka: Otokar Keršovani, 1972.

Krizman, B. 'Elaborat dra Ive Andrića o Albaniji iz 1939. godine', Časopis za suvremenu povijest br. $21977,77-89$.

Krizman, B. 'Italija u politici kralja Aleksandra i kneza Pavla (1918-1941)', Časopis za suvremenu povijest, 1/1979, 33-97.

Krizman, B. Ante Pavelić i Ustaše, Zagreb: Globus, 1978.

Milak, E. 'Italijanska diplomatija i hrvatsko pitanje 1928-1936', Istorija 20. veka 1-2/1988, 87-107.

Milak, E. Jugoslavija i Italija 1931-1937. Beograd, Institut za savremenu istoriju, 1987.

Monzali, L. Il sogno dell'egemonia. L'Italia, la questione Jugoslava e L'Europa Centrale (19181941), Firenze: La Lettere, 2010.

Paszkiewicz, J. Jugosławia $w$ polityce Wtoch $w$ latach 1914-1941, Poznan: Wydawnictwo Poznańskie, 2004.

Pavlović, K. 'Jugoslovensko-britanski odnosi 1939-1945.', Glasnik Srpskog istorijsko-kulturnog društva Njegoš, sv. 34 - juni 1975, 73-103. (Serbian Cyrillic)

Simić, B. 'Poseta grofa Ćana Jugoslaviji u januaru 1939. i pad Milana Stojadinovića', Arhiv 1-2/2018, 67-78. (Serbian Cyrillic).

Simić, B. 'Poseta pukovnika Jozefa Beka Jugoslaviji maja 1936.', u: Jugoslavija i Poljska u XX veku, ur: Momčilo Pavlović, Andrzej Zaćmiński, Paweł Wawryszuk, Institut za savremenu istoriju: Beograd, 2017, 129-142.

Svirčević, M. 'Milan Stojadinović i Hrvatsko pitanje u Jugoslaviji', u Milan Stojadinović: Politika u vreme globalnih lomova, Zbornik radova, ur. Miša Đurković. 85-97, Beograd: Zavod za udžbenike/Centar za konzervativne studije, 2013. (Serbian Cyrillic)

Vinaver, V. 'Politika Jugoslavije prema Italiji 1939-1941. godine', Istorijski zapisi op. 1, 1968, 67112. (Serbian Cyrillic)

Vinaver, V. 'Vojno-politička akcija fašističke Italije protiv Jugoslavije u jesen 1939. godine', Vojnoistorijski glasnik br.3, 1966, 73-94. 


\section{БОЈАН СИМИТ}

Институт за новију историју Србије, Београд

\section{ИТАЛИЈАНСКА ДИПЛОМАТИЈА О МИЛАНУ СТОЈАДИНОВИЋУ НАКОН ЊЕГОВОГ ПАДА СА ВЛАСТИ}

\section{Резиме}

Пад Милана Стојадиновића фебруара 1939. водећи људи фашистичке Италије доживели су као непријатно изненађење и у неку руку као потез уперен против њих. Иако су од владајућих кругова у Југославији више пута добили уверавања да се ништа није променило у односима две земље, нити у југословенској спољној политици, поверење које је било успостављено нагло је нестало. То се показало већ у априлу исте године једностраном окупацијом Албаније. Ипак, нада у повратак Стојадиновића није напуштала италијанске дипломате. Таква могућност увек је остала отворена и пожељна. Кнез Павле и представници југословенске владе били су истрајни у тврдњама да се ради о искључиво унутрашњеполитичким разлозима за његову смену и да је он препрека споразуму са Хрватима.

Може се недвосмислено закључити да је италијанска дипломатија у периоду од фебруара 1939. до Априлског рата 1941, веома жалила због одласка Стојадиновића. Ово се нарочито може рећи за министра спољних послова грофа Ћана, који је са њим остварио веома присне пријатељске односе. Томе су два основна разлога. У њему су видели човека са којим ће најефикасније остварити своје планове у Југоисточној Европи, као и због саме његове личности коју су високо ценили и уважавали. У том циљу они су стално вршили одређену врсту притиска на кнеза Павла и чланове Цветковићеве владе, а били су спремни и на директну акцију када су мислили да је Стојадиновићев живот угрожен.

Кључне речи: Италија, Југославија, Милан Стојадиновић, дипломатија, пропаганда.

(C) Faculty of Philosophy, Novi Sad, 2019

ISTRAŽIVANJA - JOURNAL OF HISTORICAL RESEARCHES 30, 256-271 